AWEJ for Translation \& Literary Studies, Volume 5, Number4. October 2021 DOI: http://dx.doi.org/10.24093/awejtls/vol5no4.9

Pp.109-139

\title{
Distorted and Limiting Semantically Divergent Translated Meaning of Arabic Loanwords in the Malay Language as Educational Instrument
}

\author{
Nur Afifah binti Abas \\ Section of Islamic Studies, School of Humanities, Universiti Sains Malaysia, Penang, Malaysia \\ Corresponding author: afifabas@student.usm.my \\ Mohd Nizam bin Sahad \\ Section of Islamic Studies, School of Humanities, Universiti Sains Malaysia, Penang, Malaysia \\ Alia Sa'ad Eldin Abusahyon \\ English Language Department, Preparatory Year, Najran University, Najran, Saudi Arabia/ \\ English Language Studies Department, School of Humanities, Universiti Sains Malaysia, Penang, \\ Malaysia
}

Received: 7/21/2021 Accepted: 9/21/2021 Published: 10/24/2021

\begin{abstract}
Historically, the language contact contributed by Muslim preachers among the Arab traders of diverse origins that some of them opted to migrate and intermarry with the local Malays, thus, intermingled with the locals that had influenced the Malay/Malaysian language to borrow more Arabic words. Some semantic properties of the loanwords are adopted, but some are adapted. This study concerns with the divergent meaning of some adapted ones. 18 Malay-Arabic homophonous loanwords were purposely sampled - (the limited sample is due to the journal words limit). It is observed that despite of their similar utterance and spelling/transliteration but they have partially or fully dissimilar meanings when being compared between the two languages. Generally, it may confuse users of both languages, specifically the Arabian students who are compulsory to pass the Malay language in order to pass their study in Malaysia as well as Malay students who are studying in Arabian countries. Moreover, it may affect their meaning in the Malay translation for the Holy Qur'an/Prophetic Tradition (Hadith). So, it is essential to engage academics of the Islamic studies, and the Malay-Arabic linguists alike with the crucial issue stemmed from the bilingual mastery level that involved both languages departing from the rising movement of re-examining and reenvision criticality in language studies. Henceforth, the Malaysian Muslim society could dynamically develop further ahead after more than 10 centuries exposed to the Arabic language rather than being stagnant in minimalism evermore.

Keywords: Arabic loanwords in the Malay language, semantic change of divergent loanword meaning; low/high bilingual mastery factor in bi/multi-lingual language, language processing and perception, the psychology and sociology of the Arabic language and Islam.

Cite as: Abas, N. A., Sahad, M. N., \& Abusahyon, A. S. (2021). Distorted and Limiting Semantically Divergent Translated Meaning of Arabic Loanwords in the Malay Language as Educational Instrument. Arab World English Journal for Translation \& Literary Studies 5 (4) 109-139.

DOI: http://dx.doi.org/10.24093/awejtls/vol5no4.9
\end{abstract}

Arab World English Journal for Translation \& Literary Studies 
AWEJ for Translation \& Literary Studies Volume, 5 Number 4. October 2021

\section{Introduction}

The Malay or Malaysian language is spoken and written nationwide in Malaysia primarily by the Malays who are defined by the Article 160 within The Federal Constitution of Malaysia:

"Malay" means a person who professes the religion of Islam, habitually speaks the Malay language, conforms to Malay custom and-

(a) was before Merdeka Day born in the Federation or in Singapore or born of parents one of whom was born in the Federation or in Singapore, or is on that day domiciled in the Federation or in Singapore; or

(b) is the issue of such a person;

(The Malaysian Commissioner of Law, Revised Act 2010, p.153).

Malays are synonym with the religion of Islam because of the codified law stated as the official religion of Malaysia as in the Federal Constitution, Part 1: The States, Religion and Law of the Federation in Article 3 on Religion of the Federation stated:

\section{3. (1) Islam is the religion of the Federation; but other may be practiced in peace and harmony in any part of the Federation)}

(The Malaysian Commissioner of Law, Revised Act 2010, pp.19-20)

The religion of Islam brought together with it the influence of the Arabic language and culture through its function in Islamic practices (Versteegh, 2001, p.471) in the Islamic countries (Khrisat \& Majiduddin Sayyed Mohamad, 2015, p.134). The earliest archaeological evidence found in the Malay Archipelago that supports the notion was a grave board of a Muslim cleric dated 48 Hijri. It was carved with Arabic calligraphic fonts of Thuluth and Kufi types belong to a 'Sheikh Rukunuddin'. Other tombs were found later in Barus, somewhere in the west coast of North Sumatra. They were adorned with some beautiful carvings of some Qur'anic verses. The most substantial influence was the initiation of 'Jawi' writing which is Malay-ized writing adapting Arabic fonts. The writing was first detected in 702 Hijri (Amat Juhari Moain \& Wan Mohd Saophy Amizul Wan Mansor, 2016, p.3).

Apart from that, historically the Malay people had been mixing with the Arabian traders since 9th - mid 10th CE (Watson-Andaya \& Andaya, 1982, pp.53-54) that was earlier period than the days of "Ketuanan Melayu Melaka" [tr. Malacca Malay Sultanate Reign - a prominent ancient Malay kingdom] by few centuries where they had attracted the Malay rulers to embrace Islam. Some of the traders decided to migrate to Tanah Melayu [tr. Malay Land: ancient name for Malaysia) after being Islamic preachers for a long time there. Presently, there are so many descendants of intermarried Arabian preachers cum traders. The intermingling due to social relation and interaction had exposed the Malays to borrow more from the Arabic language into the Malay language. It also contributed a lot to the expansion of the religion of Islam acceptance peacefully (Noor Azlina Zaidan et al., 2015).

Interestingly, Versteegh shared a record of an immense entry of Hadramis (Arab people belong to Hadhramaut, Yemen) into the Malay region in the 19th century. Their figure tripled to a staggering 30,000 individuals in $1905 \mathrm{CE}$ compared to 11,000 individuals in $1885 \mathrm{CE}$ (Versteegh, 2001, p.499). It tallies the researcher's own personal observation and knowledge being part of the 
AWEJ for Translation \& Literary Studies Volume, 5 Number 4. October 2021

"historical evidence" as coined by Ricquier (2019, p.11). Some of them enjoyed the prestige of the above provisional law, got 'neutralized', thus, became Malaysian citizens. Most of their descendants innately keep the trans-generational tradition heritably to serve for the Arabic language and the religion of Islam in Malaysia until today. So, no wonder there are so many Malay words are similar to Arabic words.

There are more than 2000 Arabic loanwords were registered in 'Kamus Dewan' (Dewan Malay Dictionary) of 4th edition - majority was altered to fit Malay utterances. Even the word

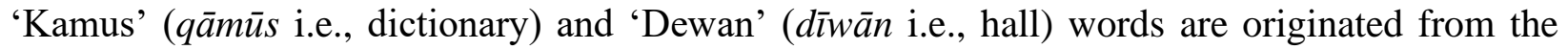
Arabic language. The amount is considered 'big' although it is very scarce to find people who could perfectly utter Arabic wordings or speak the Arabic language fluently with complete understanding of the language in Malaysia. Unless, if they learned it, or are professionals or already used to the language or at least fluent with the Holy Qur'anic recitation (Amat Juhari Moain \& Wan Mohd Saophy Amizul Wan Mansor, 2016, p.5). Another research concluded that there are 1791 Arabic loanwords in the Malay dictionary (Noor Azlina Zaidan et al., 2015). Although most of them maintains their meanings as in their Arabic origins, some are altered or diverged.

Relating language to the trade again, this time via waterway, which is until now a cheaper way for travelling and transporting commodities by ships, especially in massive quantity specifically within global import and export activities. Hence, it is not surprising for the Malay language to loan such a big number of Arabic words as the Peninsular Malay geographically located in the middle of a very strategic and vital waterway route for both global directions: to the east and the west, plus, the southern globe through the Straits of Malacca, the Indian Ocean, and the South China Sea that surround the Malaysia. Naturally, they attract many traders from different countries to many of its dominant international water ports. The seaports also attract global political powers to conquer Malaysia as owning it is a great income mining from common taxes and levies imposed. Thus, historically it was always exposed to many either foreign conquest or colonization by Indian, Chinese, Portugal, Dutch, British, Chinese communist, and Japanese powers, apart from the nearby kingdoms like the Thai and Khmer powers (Watson-Andaya \& Andaya, 1982, pp.11-71).

Such rich history had exposed it to plentiful language contact platforms; thus, the Malay language tends to directly or indirectly borrow words from various languages in the world. Apart from our discussed Arabic language, it also borrows from the European languages like the Spanish, Portuguese, Dutch, French, German, Greek, Italian, Latin and English; as well as from other Asian languages: Hebrew, Persian, Chinese dialects, Indian languages: Sanskrit, Hindi/Urdu, and Tamil; plus, Thai, Japanese, and surprisingly, - even the Russian language (Jones, R. (Gen. Ed.), Grijns, C.D. \& de Vries, J. W. (Eds.) 2007, p.xii)! Seemingly, it is inevitably reflects "Malaysian geopolitical, economic, cultural, and social events along the histories of its speakers" (Stockwell \& Minkova, 2002).

Actually, the Arabic language ranks second right after the Sanskrit language as the second major donor language to the Malay vocabulary (Jones, R. (Comp.), 1978; Jones et al., 2007). Among Arabic words borrowed are 'abjad', 'Ahad', 'ahli', 'baki', and 'tarikh' (Wan Muhammad Marwan lsmail \& Wan Moharani bin Mohammad, 2009). Yet, the role of the Arabic language is a 
AWEJ for Translation \& Literary Studies Volume, 5 Number 4. October 2021

neglected field of research (Azirah Hashim \& Leitner, 2016). So, it needs more researches to discover more about it.

\section{The Influence of the Arabic Language on Other Global Languages}

Conversely, it is well known that the Arabic language has etymologically influenced almost all languages that exist (The Mother Tongue Center - Arabic Language Learning, 2017; Versteegh, 2001), not only limited to the Malay language. Even the European languages included due to its rich history of the Andalusian Islamic Umayyad conquest and lengthy period of reign in the Spain. It was the dissemination of knowledge from them that sparked the Western Enlightenment and Renaissance, which had initiated their establishment of present advancing scientific bequest (Eaton, 1985).

Actually, along with that phase of the Andalusian period, the Arabic language had been highly regarded as 'the center of culture' where other languages were impacted by it rather than vice versa (Sapir, 1921). Usually, political factors, migrations, or trade routes are expected elements to create possible language contact situations, which lead to the process of language borrowing. The results of certain study on loanwords and language contact would reveal many aspects of concealed historical information about the speakers in question (Ricquier, 2019).

Primarily, history concluded that one (country/nation/human) which/who was conquered, tends 'to imitate' the conqueror in every way that brings him closer resemblance with regards to language, appearance, and style to gain social prestige (Abu Amsha, 1997). Ibn Khaldun, a Muslim sociologist who had promoted this theory of 'imitation' (Abu Amsha, 1997) seemed to resonate with an Italian linguist Gusmani who also favored the term 'imitation' (tr. It. imitazione) too in making sense of such cultural exchange (Ottolini, 2014, p.7).

Another pertinent aspect is the religious function and identity related to the Arabic language where people acquired it while gaining knowledge about Islam as a new religion of the region like the Malays were Hindu before, and gained some Sanskrit loanwords from that religion previously (Jaspal \& Coyle, 2010). However, usually, they still needed people who were bilinguals of both languages to a certain level. Sometimes, their level of bilingualism and acceptance of others in acquiring knowledge from those people led to imperfect importation from a language to another language (Versteegh, 2001, p.502).

\section{Borrowing and Language Contact Phenomena}

Linguistic term: 'borrowing' usually refers to lexical borrowing. A phenomenon usually caused by language contact. Language contact is a speech communication between two or more language communities including dialects of a language or common supra-dialectical language. It can be fit into bilingual or multilingual contacts as linguistically they share most of the similar properties (Rozencvejg, 1976, p.1). Information about previous interactions that occurred in encounters between different societies is a valuable means in discovering the realities of their borrowed lexicons or loanwords (Ricquier, 2019, p.1). Language contact is a common (Ottolini, 2014) and natural phenomenon (Tarev, 2012). The borrowing processes usually depend on certain setting of language-contact, which is the main prerequisite for language to 'imitate' during speech exchange 
that occurred between speakers of different languages. Due to this reason, words are also considered as 'transferrers of culture or an instrument of cultural exchange', consequently, loanwords are "ambassadors" of donor language in a recipient language.

Conversely, higher ranked language of an era also could borrow from lower-level language due to the absence of words for certain concepts or culture in its society. Here, the borrowing is considered of necessity. Finally, any language logically absorbs "some words from other languages to refer to places, things, processes, and ways of behaviour, organization, or thinking, for which words or phrases were formerly not available or convenient in the recipient language" (Weinreich, 1968; Winford, 2003). Subsequently, borrowing became the most common and immediate outcomes of cultural exchange globally all the time (Ottolini, 2014, p.1).

These phenomena are specifically being investigated in details by linguistic scholars who base their studies on historical foundations and searching a conclusive model within a foreign language in contact and other contact-induced change in languages where Manfredi, Simeone-Senelle \& Tosco (2015) observe that the borrowed item always being identified through examining structural and socio-historical properties of its language, which is in tune to what Haugen $(1950, p .212)$ had explicitly mentioned that the process needs etymological comparison between the donor and recipient language of any language item being investigated.

In essence, the original substance of any language is constantly subjected to linguistic changes, and naturally will be further reformed by the extralinguistic factors such as sociocultural changes, technological innovations, and encounters with other speech communities (Ricquier, 2019, p.2). Any contact language setting will vulnerably expose any language to either of these two (2) types of changes:

1) Convergent Change: happens within the contact languages in the form of assimilating the linguistics properties of each other like grammatical rules to produce the results of contact.

2) Divergent Change: is a result of deviation occurred in contact languages that influenced sort of differentiation on the linguistic characteristics of the languages.

The factors could vary from problems of contacts; be it sociological, ethnographic, psychological or linguistic. Primarily, the results concern linguistic results of the contact between bilinguals or multilinguals alike (Rozencvejg, 1976, p.2).

\section{Lexical Borrowing}

Haspelmath (2009, p.36) defined lexical borrowing is simply "a word that at some point in the history of a language entered its lexicon as a result of borrowing (or transfer, or copying)". It is an unavoidable outcome out of contact between speech communities (Robins, 1964, p.313); and known for its role in enriching a language but does not necessarily lead to the loss of its specificity and identity (Tarev, 2012). According to linguists the factors that lead to borrowing words from a language are divided into two types either extralinguistic or linguistic proper.

The ones within the extralinguistic reasons are:

1) Cultural exchanges among nations, 
2) Presence of oral or written contacts between countries with different languages,

3) Increasing interest in learning language,

4) Prestige of the donor language (which sometimes leads to borrowing by many languages from one language due to the appearance of internationalisms or lingua franca of certain era),

5) Passion of specific social strata towards the culture of another country;

6) Linguistic culture of social strata that introduces a new word

Meanwhile proper linguistic reasons include:

1) An absence of or inadequate equivalent vocabulary for the new object or concept in the recipient language

2) Tendency to use foreign loanwords instead of descriptive phrases exist for an item,

3) The desire to improve and preserve the communicative distinction of lexical units, which is achieved through elimination of polysemy or homonymy in the recipient language,

4) The need to specify appropriate meaning in order to distinguish some differences of meaning through attaching them to different words,

5) Expressiveness tendency that appears out of a foreign-language stylistic synonym,

6) Growth in the recipient language of words, which are characterized by similar elements of lexical borrowing activities (Tarev, 2012).

Interestingly, (Winford, 2003, p.2) had observed that there are situations, where borrowing also may happen without any physical social contact where the contact with other languages was in the medium of written form only, either through literature or religious texts and articles through the changing agents of society like writers, translators, and journalists. Similar ideas supported by (Loveday, 1996, p.17) who suggested the term "distant contact" for a dominant non-bilingual donor language. Winford (2003) updated the current global communication style, which could be via contemporary channels such as radio, television, and the internet that had simplified our exposure to borrowing phenomena. It simply spreads multicultural vocabulary that exposed through introduced items in films, songs, novels, academic research, food and drink; fashion, and so forth, into other recipient culture either mono- or bi-directionally.

\section{The Role of Bilinguals in the Background of the Borrowing Recipient Language}

McMahon (1994, p.204) and Haspelmath (2009, p.36) proposed that in borrowing the processes either unrouted the adopting way where the donor language is adopted as it is in the donor language or being adapted to fit the native recipient language. That depends on the factor of bilingual mastery (Haugen, 1950). The presence of bilinguals in a recipient language, especially among the native speakers themselves is essential in sharing what they understood within the both sides of the languages in bilingualism (or multilingualism for more than 2 languages); unlike the monolinguals who depend on the native language alone as a medium to understand. According to Weinreich (1968, p.ivi: pp.59-60) bilinguals may urged to borrow from the other language they knew when they sensed that:

(a) there is a need for enrichment where absence of equivalent words in the semantic fields of his/her language

(b) there is a need to acquire some loanwords to earn prestigious social status from the language acquired or to tune in into a certain slang 
AWEJ for Translation \& Literary Studies Volume, 5 Number 4. October 2021

(c) there is a need for transferring some words into his/her language when exposed to the other language

Matras stated the fact that the borrowing is initiated by the occasional use of second-language being inserted into the speech of bilinguals (Matras, 2009, p.147). Usually loanwords are nouns because Whitney (1881) reasoned: "By universal consent, what is most easily transferred from one tongue to another is a noun; the name of a thing is language-material in its most exportable form. As other form is less manageable" - similar ideas found in (Matras, 2009, p.172), (Myers-Scotton, 1993, p.240), (Thomason \& Kaufman, 1988, p.73), also endorsed over higher borrowability together with (Van Hout \& Muysken, 1994, pp.54-55).

Are Arabic Loanwords in the Malay Language are Considered Cognates?

A loanword is a word from a donor language either being adopted or adapted or incorporated into a recipient language without translating it in local usage like the 'calque' category. Identifying loanwords is plausible through verifying them whether they are cognates or not. Contrary to cognates, which are similar words in two or more languages, that share an etymological origin (Sapir, 1921) i.e., parent language like the Old German or Greek languages are to more modern languages like English, French, and Spanish. There are cognates that had evolved into similar, different or even opposite meanings of the original words. Yet, most of them are with similar sounds or letters in the spelling/transliteration. As literally goes, the word 'cognate' derives from the Latin noun 'cognatus': "blood relative". Each language may have changed as they developed separately (Masson, 2013).

However, there are words that sound similar, but do not share the same root etymologically, thus, they are called 'false cognates' like those words with similar utterance in the Malay language and the Arabic language yet they are not related in the family tree of languages because the Malay language is a non-Semitic language out of the Austronesian family languages, unlike the Arabic language, which is under the Semitic family languages (Testen, 2019; Wan Muhammad Marwan lsmail \& Wan Moharani bin Mohammad, 2009, p.ix; Crystal, 1994 ).

\section{Nature of Loanwords}

Among the activities grouped under language borrowing: calques, loanwords, and semantic loans. This research specifies on the category of 'loanword'. It is identified by its different phoneme and morpheme exported from the donor language when the recipient language belongs to different language families like the Malay and the Arabic languages as described in (Ricquier, 2019). Boris V. Tarev found out that loanwords permeate into the recipient language through oral medium of introduced special terminology/ies, press, written correspondence communication and translation of specialized field/s from foreign literature. Factually, the written medium left more noticeable traces of penetration and assimilation because it happened in a much more systematic manner (Tarev, 2012).

Logically, the majority of loanwords in most languages (80\%) are nouns because words from that category do not attach to any 'prefix' and are more visibly linked to religious connotations (Karũrũ, 2013, p.2) i.e., Islam - in the case of the Arabic language influence in the Malay language. 
AWEJ for Translation \& Literary Studies Volume, 5 Number 4. October 2021

Like him, Haspelmath described that loanwords are always in noun word form (i.e., lexemes) rarely in phrase form, and usually found difficult to fit the recipient language original system (2009, p.37). However far the dispute goes, the term 'loanword' is still immensely being used and accepted among the linguists. Notwithstanding, Haugen recorded that the English term "loanword" itself is a loanword derived from the German word of 'Lehnwort' (Haugen, 1992, p.197).

Despite the need for relative historical chronology to verify each loanword accurately (Ricquier, 2019 , p.7) unfortunately, it is complicated to precisely determine through which route Malay acquired each of its Arabic loanwords. Many loanwords betray a Persian link, possibly via Indian link rather than directly loaned from the Arabic language (Versteegh, 2001, p.499).

\section{Semantic Change}

The word 'semantic' derives from a Greek word 'semantikos'. Michel Breal, a French linguist, was the first mentioned in his book: 'Essai de Semantique' (1897 CE) that the earliest evidence of such studies could be traced back to Aristotle's era. It was a process where the precise meaning of words was examined in language usage to avoid distortion of meaning out of misunderstanding or misinterpretation (Wan Muhammad Marwan lsmail \& Wan Moharani bin Mohammad, 2009, pp.9$10)$.

Within this field of studies there is a phenomenon termed as semantic change where a word changed its meaning from its original language (donor) after being adapted into another language (recipient). Semantic change occurred due to cultural context of the recipient language where the vocabulary develops. Some speakers alter these loanwords as they are using them creatively; on the other hand, some hearers sometimes altered what they heard as they mistakenly heard/interpreted what the speakers had actually uttered due to unfamiliarity. Most of these alterations are accidental and short-lived; yet, some are resistant (Traugot, 2019, p.2). The change was usually induced by the incongruence between the real meaning of the uttered word in any donor language and the misunderstood meaning/mistakenly heard utterance in the recipient language (Traugot, 2019, pp.9-10).

\section{The Statement of Problem}

The semantic change problem that the researchers focused was on the selected homonymous (similar sounds or spellings in both languages) (WordReference, 2021) Arabic loanwords in the Malay language that may distort and divert the accuracy of their meaning in the donor language when they were understood in their current meaning of the Malay usage. This may induce confusion originated from the Malay meaning of those loanwords either for those involved in the compulsory Malay language course for foreign students who are studying in Malaysia, especially among the Arabs of them, those in the Islamic or linguistics studies, and Malaysian students who are studying in the Arabian countries. Hence, it is very critical to get academics of the Islamic studies and the Malay-Arabic linguists alike engaged on the crucial issue to re-examine and reenvision criticality in language studies (Kubota \& Miller, 2017). The impact is worse within the Islamic studies that deal with the translation of the Holy Qur'an and the Prophetic Tradition (Hadìth). It would be compromised because it could be categorized as deviant or heretic as the meaning must follow the Arabic language, especially of the Quraish tribal usage as the main 
principle in the interpretative activities and processes of (Tafsir) due to their sacredly ranked as the revered primary sources in Islam (Hussein, 2001, 2019).

\section{Level of Bi/Multilingualism of the Recipient Society}

It was a long call in the Islamic studies for such loanwords to be checked and revised their lexical importation (Hafez, 1996, p.401). Apart from that, the level of bilingual mastery of a society, especially the importers of the words are primarily considered the most vital determinant for the cultural exchange processes. It correlates with the extent of language change that would occur in a recipient language in borrowing other's language. It depends on how much the bilinguals developed their bilingualism. The misunderstood context and meaning always originated from the guessing or assuming mind of the monolinguals and the underdeveloped bilinguals - in the adapted category.

The fully developed bilinguals differ from those who are underdeveloped bilinguals or monolinguals as their mind is "the clearest, closest, and fastest to process the languages" when language contact happens - adopted category. They are also able to moderate the interference of the other language in their speech like middle persons to the other two (2) categories monolinguals and underdeveloped ones in helping them understood too (McMahon, 1994, p.204). Plus, the time factor will intensifies the need for more borrowing between the languages in contact (Thomason \& Kaufman, 1988, pp.74-76).

Albeit the facts discussed by the contemporary linguists; (Whitney, 1881, p.16) had long recognized that the loanword usually becomes an integral part of the recipient language "nativized" - except to the learned people. The native speakers would not even aware about it due to being 'assimilated'. However, sometimes intensive borrowing leads to alteration of the phonetic system of the recipient language. Yet, if the donor language became more familiar through its source of phonology and syntax, then, newer and more accurate version of the foreign item will be imported into the recipient language (Bloomfield 1967, p.447). Therefore, Haspelmath (2009) added the status of 'loanword' needs to be identified with certainty through examining both recognized donor and recipient languages.

Also, the written origin of loanwords is more accurately imported by professionals who mastered the bilingualism of both languages who were/are more confident about the meaning of the certain types of language applications (uslüb), and instinctively could detect or sense what is wrong with any word. In comparison to the ones nativized through heard and guessed foreign words without adequate level of bilingualism between the Arabic and the Malay languages - the authority is obscure and commonsensically subject to many mistakes as (Higa, 1979, p.284) perceptively concludes:

\section{"...the intellectuals tend to borrow foreign words through the eye, while others borrow through the ear".}

The Role of Arabic Words and its Meanings in Islamic Education/Studies 
Historically, Abd al-Qāhir Al-Jurjān̄̄1 (d. 1078 M) was the first to concern about the meaning of the Arabic words due to his involvement in his study about the Inimitability of the Holy Qur'an (I'jāz al-Qur'ān) as in (Solehah Yaacob \& Adli Yaacob, 2014). He was a Muslim Persian who master Arabic linguistics, thus, familiarity with the Arabic language was at higher level compared to common Malaysians who are generally not fully developed bilingually with the Arabic language unlike the English language. Persia is the present Iran had accepted Islam earlier than Tanah Melayu (Malaysia now) when the Arabic language gained global dominant status then and had been adapting the donor language until today as part of daily life communication.

Similar conserving concern had been voiced out again contemporarily by a renowned Islamization of Knowledge scholar: Prof. Dr. Ismai'il al-Faruqi that the usage through listening, transliteration or translation into another language had exposed Arabic words to "distortion of meaning like some of its meanings suffer change, loss or obliteration of consciousness." It ends up with "a serious threat to the continuity of the Islamic understanding" (Al-Faruqi, 1986, p.14). Recently, his opinion had again sparked interest to explore the authentic usage of the language in a linguistic domain of Islamic Studies and Sciences that was once reserved for the Arabic language (Nurul-ikhlas Arshad \& Mohamed Ismail Ahamad Shah, 2014, p.110).

So, it is unsurprising for the similar concerns to surface anywhere again, especially among Malaysian speakers' language during their involvement in the Islamic and lingual education in general usually due to religious factor. Speaking specifically in Malaysia setting; Malaysians may get more exposed to the Arabic language if the parents opted for the Islamic stream education from the budding pre-schoolers aged four or five years old. Islamic stream education plays a special role for Muslim Malaysians' identity regardless of their racial background because it indirectly provides religious identity education. Yet, being 'the people of the soil' or termed as 'Bumiputera', the Malays seemed to put more emphasis on it, as statistically, they comprise the majority of the nation compared to Chinese or Indian or other ethnic Muslims (Wikipedia, 2021).

Actually, this trend already existed even before Malaya ${ }^{2}$ established its independence from British colonization in 1957 up to the formation of the Malaysian Federation in 1963. It was initially through Islamic schools called 'pondok' or 'madrasah'. Today, it continues as an important educational stream because Muslims, especially Malay Bumiputeras' constitutional affiliation to Islam (Airil Haimi Mohd Adnan, 2017). This educational stream may last until the tertiary level of education in the college/university throughout diploma/degree/masters/doctoral degree with similar lingual problem/s, especially semantic and translation related problems as Malaysia is more bilingual with the English language than the Arabic language, which level of bilingualism is too low on average - used only for religious-related purpose - mostly for the Qur'anic recitation and religious rituals like prayers (solat) even without understanding the meaning generally, except for those learned the language, thus, such problems keep inexorably occurring, especially being more aware of it at tertiary Islamic or linguistics specialized studies.

The Distorted Arabic Loanwords within Malay Translation/Nativized Vocabularies

${ }^{1}$ Abu Bakr, Abd al-Qāhir bin Abd ar-Rahman bin Muhammad al-Jurjān̄̄ ( $400-471$ or 474 A.H./1078 AD)
2 Tanah Melayu was named 'Malaya' during British occupation time before finally being named 'Malaysia'.

Arab World English Journal for Translation \& Literary Studies

ISSN: 2550-1542 | www.awej-tls.org 
The researcher herself asserts having personal experience facing misleading translated Arabic words or sentences or concepts/contexts throughout being educated in the Islamic educational stream from kindergarten to the university levels. It is indeed commonly happened due to the limitation of bilingualism level of the Arabic-Malay language proficiency among the local or Arabian teaching force alike. It is a very exceptional phenomenon to be blessed by teachers who are flatteringly fluent in both languages; consequently, such problems will be avoidable.

Specifically, another type of personal experience when asked by a fellow Malay friend: "whether the word 'marah' (anger/angry) is originally from 'amarah' as mentioned in Malay as in 'nafsu ammarah' adapted from a verse in the Qur'an (Q12:53)?" and also 'fitnah' by students as in (Q2: 191), those words do not directly and literally synchronize at meaning level in spite of their similar sounds. These incidents had long sparked questions and curiosity within the researcher's self.

Again, similar to this phenomenon was realized during the researcher's reading of the Malay translation for the Holy Qur'an, which is accompanied with it the Arabic words/wording directly together, usually placed above the Malay translation as Ahmad Basmeih's Malay Translation from the Qur'an Android application. It needs a person to be familiar with the Arabic language and its usage, especially in the translation more specifically important for the Qur'an to sense the difference. It seems we need to create more awareness and revision on the regulations and principles regarding borrowed items usage, plus, to purify the Islamic Arabic terms (Nurulikhlas Arshad \& Mohamed Ismail Ahamad Shah, 2014, p.116) to avoid confusing or erroneous meanings.

\section{Methodology}

Accordingly, we adopt a qualitative (text-related) research approach using mainly comparative analysis on observed documents: translation of the Holy Qur'an, the Arabic-Malay-English dictionaries, combining personal observation and experiences through first-person perspective analysis within broad phenomenology methodology on some sampled Arabic words that are used also in the Malay language. First-person perspective analysis investigates one's self-awareness as a crucial process to understand what it means to be a self in experiencing a certain phenomenon to get a conceivable explanation (Zahavi, 2005). In spite of the utterance and sound similarity (homonyms), yet, surprisingly; they differ in meaning either fully or partially.

After some time of observing, we sampled some words based on 'deviant case sampling' method (Cresswell, 2007) i.e., the meaning that deviates from the Arabic language, in order to apply a comparative analysis on the set of loanwords we observed to prove our assumption that there IS divergence of meaning between the donor and the recipient languages usage of the words (based on the dominant meaning in practical usage of the society). The comparative analysis is justified by suggestion from Ricquier (2019, pp.1 \& 12) that it is suitable in linguistic research in order "to identify loanwords and to distinguish them from inherited vocabulary, it is necessary to apply the comparative linguistic method." 
AWEJ for Translation \& Literary Studies Volume, 5 Number 4. October 2021

The definitions of the selected words in the Malay language are referred to the website of Dewan Bahasa dan Pustaka (DBP) [tr. Malay Language National Premier Reference Dictionary] (Dewan Bahasa dan Pustaka Malaysia, 2017) and the Arabic definitions are translated into English meaning from Almaany.com website (Almaany, 2019).

\section{Selected Loanwords:}

They are studied via library research by comparing their meaning in Arabic and Malay dictionaries. The selected words are alphabetically list:

1. Fitnah (فنت) - fitnat

2. Had/Hudud (حد/حدود) - had/hudūd

3. Hasrat (حسرت) - hasrat

4. Ihsan (إحسان) - ihsān

5. Ijazah (إجاز) - ijāzat

6. $\operatorname{Ikrar}($ إقزاز) - iqrār

7. Insaf (إنصاف) - inșâf

8. Jenazah (جنازة) - janāzat

9. Khalifah (خليفة) - khaliffat

10. Khalwat (خلوة) - khalwat

11. Malu (ماله) - mā luh (colloq. for mā lahu)

12. Marah (أمارة) - ammārat

13. Muslihat (مصلحات) - muṣlihāt

14. Nakal (نكال) - nakāl

15. Rogol (رجل) - rajul

16. Sakit (ساكت) - sākit

17. Sejarah (شجرة/شجار +ة//سيجارة) - shajārat/shijārat/sijārat

18. Tertib (ترنبب) - tartīb

The researchers will also share their experience where the meaning of those words in the usage of both languages concerned as being used by the native speakers' context phenomenologically via self-reflection analysis methodology from personal experience of living among native speakers (in the Sudan, Saudi Arabia, Egypt, and Jordan) in the methodology and discussion sections. The observed idea that the words do have divergent meaning is peer debriefed, reviewed, and endorsed for validation by an Arabian researcher who is an English linguist. Peer debrief "acts as a sort of critical detective and is similar to an auditor." Many authors have recommended applying peer debriefing to improve the trustworthiness and the credibility of a research project (Lincoln and Guba, 1985; Spall, 1998; Janesick, 2011; Spillett, 2003) in (Janesick, 2015).

\section{Results}

Table 1 serves to demonstrate the different meaning in the Malay and the Arabic languages respectively, for the selected homophonic loanwords.

Table 1. The Comparison of Meaning between the Malay and the Arabic Languages of the Selected Words

\begin{tabular}{|l|l|l|}
\hline No. & Word & Meaning in \\
\hline
\end{tabular}

Arab World English Journal for Translation \& Literary Studies 
AWEJ for Translation \& Literary Studies Volume, 5 Number 4. October 2021

\begin{tabular}{|c|c|c|c|}
\hline & & Malay language & Arabic language \\
\hline 1. & Fitnah & 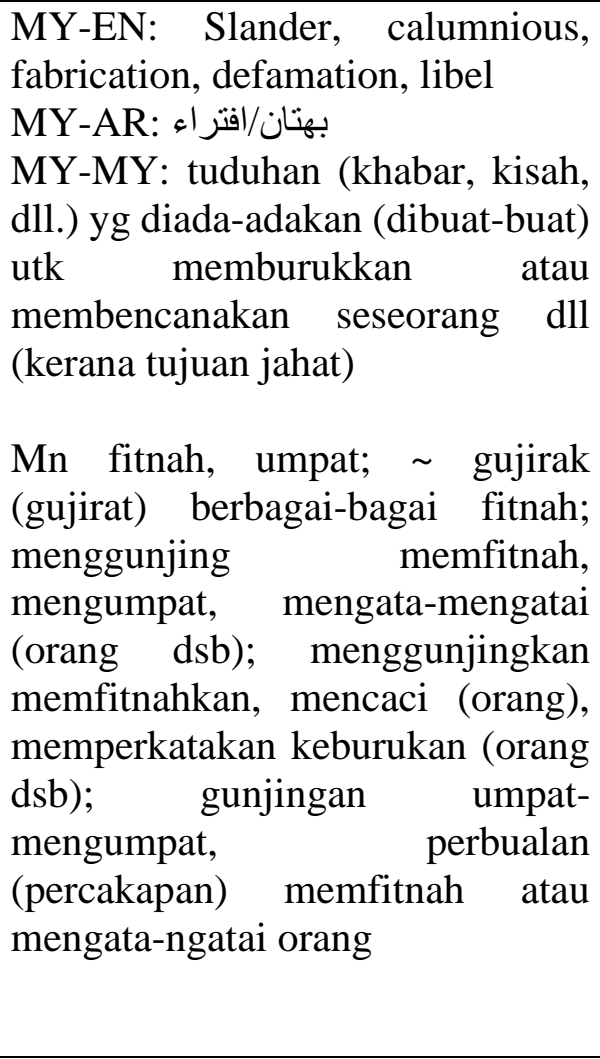 & $\begin{array}{l}\text { AR-EN: appeal; attraction; } \\
\text { enticement; seduction; temptation; } \\
\text { bewitchment; captivation; charisma; } \\
\text { charm; enchantment; fascination; } \\
\text { glamor; infatuation; magic; spell; } \\
\text { commotion; disorder; disturbance; } \\
\text { riot; sedition; strife; trouble; tumult; } \\
\text { turmoil; unrest; adversity; } \\
\text { - unfavorable or unfortunate } \\
\text { conditions, event or circumstances; } \\
\text { trouble, calamity, disaster; } \\
\text { misfortune, affliction } \\
\text { - pain; suffering; distress or thing } \\
\text { that causes suffering } \\
\text { - catastrophe, disaster, serious } \\
\text { misfortune (for example; an } \\
\text { earthquake, becoming blind, etc.) } \\
\text { - great or sudden misfortune; terrible } \\
\text { accident } \\
\text { - be exposed to danger, hunger, } \\
\text { criticism } \\
\text { - ordeal; trial; affliction }\end{array}$ \\
\hline 2. & Had/Hudud & $\begin{array}{l}\text { MY-EN: Limit } \\
\text { MY-AR: حد محدود } \\
\text { MY-MY: } \\
\text { 1. batas } \\
\text { 2. hingga (sampai) ke, setakat: } \\
\text { 3. menentukan hadnya (masanya, } \\
\text { banyaknya, luasnya, } \\
\text { perenggannya, dll), membatasi } \\
\text { 4. mengkhususkan, menguntuk- } \\
\text { kan: } \\
\text { 5. ditentukan batas atau } \\
\text { perenggannya, terbatas } \\
\text { Ar 1. (jamak bagi had iaitu hudud) } \\
\text { batasan atau per-aturan; } \\
\text { 2. hukum yg telah ditetapkan oleh } \\
\text { Allah yg tidak boleh diubah-ubah } \\
\text { oleh manusia, seperti hukum } \\
\text { bunuh (qisas), zina, murtad, dan } \\
\text { minum arak. }\end{array}$ & $\begin{array}{l}\text { AR-EN: Limit/ } \\
\text { - be a limit to } \\
\text { border; borderline; boundary; } \\
\text { confine(s); frontier; limit; mete; } \\
\text { outline } \\
\text { - line that marks a limit; dividing line } \\
\text { - the border between two countries; } \\
\text { the district on each side of this; the } \\
\text { borders between settled and } \\
\text { unsettled country } \\
\text { Definition: } \\
\text { alleviation; } \\
\text { confinement; control; curb(ing); } \\
\text { curtailment; decreasing; lessening; } \\
\text { limitation; mitigation; moderation; } \\
\text { reduction; repression; restraint; } \\
\text { restriction } \\
\text { degree; extent; level; measure; point; } \\
\text { standard }\end{array}$ \\
\hline
\end{tabular}




\begin{tabular}{|c|c|c|c|}
\hline & & & $\begin{array}{l}\text { margin; brim; brink; edge; end; } \\
\text { extreme; extremity; terminal point; } \\
\text { terminus; verge; } \\
\text { bound } \\
\text { - to keep or restrict (within certain } \\
\text { limits) or to shut up; imprison } \\
\text { - show by drawing or describing: } \\
\text { portray } \\
\text { - to state or fix the limits of an area } \\
\text { - demarcate; delimit } \\
\text { - be affected by extreme } \\
\text { (suppressed) anger; be kindled with } \\
\text { anger } \\
\text { - became suddenly angry or active } \\
\text { - be (become, get) excited; irritated; } \\
\text { incited } \\
\text { - very furious; outraged; wrathful } \\
\text { - be annoyed, displeased, enraged, } \\
\text { furious } \\
\text { - be, become or get hot-tempered; } \\
\text { provoked } \\
\text { - burst out with strong anger } \\
\text { - frenzied } \\
\text { - burst into strong feeling } \\
\text { - show violent anger } \\
\text { - be agitated or deeply stirred } \\
\text { - reduce; repress; restrain; } \\
\text { Hudud: The limits ordained by } \\
\text { Allah. This includes the Islamic } \\
\text { punishment for crimes }\end{array}$ \\
\hline 3. & Hasrat & $\begin{array}{l}\text { MY-EN: wish, aspiration, desire, } \\
\text { eager } \\
\text { MY-AR: رجاءتمنى } \\
\text { MY-MY: } \\
\text { 1. sl hasrat (kehendak) utk } \\
\text { mendapat sesuatu, hasrat supaya } \\
\text { terjadi sesuatu: } \\
\text { 2. percaya akan, menggantungkan } \\
\text { nasib dll. kepada, mempercayai, } \\
\text { harapan } \\
\text { 3. perihal mengharapkan } \\
\text { 4. keinginan yg kuat utk memiliki/ } \\
\text { melakukan sesuatu } \\
\text { 5. rasa, perasaan; }\end{array}$ & $\begin{array}{l}\text { AR-EN: Regret } \\
\text { Verb: be or become regretful } \\
\text { - to become broken-hearted } \\
\text { - be or become sad } \\
\text { - be or become regretted } \\
\text { - have a strong emotional longing; be } \\
\text { filled with compassion or tenderness } \\
\text { - grieve } \\
\text { - cause grief or great distress or } \\
\text { suffer grief } \\
\text { - sadden or make sorrowful } \\
\text { - cause somebody to become sad } \\
\text { Yā hasrata - expression of } \\
\text { regret/grievance }\end{array}$ \\
\hline
\end{tabular}

Arab World English Journal for Translation \& Literary Studies 


\begin{tabular}{|c|c|c|c|}
\hline & & $\begin{array}{l}\text { 6. gagasan, idea; } \\
\text { 7. sl cipta, angan-angan, fikiran } \\
\text { 8. cinta, rindu (akan) } \\
\text { 9. maksud, tujuan yg hendak } \\
\text { dilaksanakan } \\
\text { 10. bercita-cita } \\
\text { 11. berniat (akan) }\end{array}$ & \\
\hline 4. & Ihsan & $\begin{array}{l}\text { MY-EN: Courtesy } \\
\text { MY-AR: متأدب/ } 13 \\
\text { MY-MY: perbuatan yg baik; } \\
\text { kemurahan hati; kebaikan } \\
\text { perbuatan yg baik; kemurahan } \\
\text { hati; kebaikan } \\
\text { belas ihsan: } \\
\text { MY-EN: compassion } \\
\text { MY-AR: شفقة } \\
\text { MY-MY: Kesian, simpati }\end{array}$ & $\begin{array}{l}\text { AR-EN: charitable deeds, the doing } \\
\text { of good [Islamic], beneficence } \\
\text { [Social], charity [Islamic], (be) } \\
\text { good, (do) good, kindness, to render } \\
\text { good for evil [Islamic] [Koran } \\
\text { Words] } \\
\text { verb: become very good at } \\
\text { - bring to perfection } \\
\text { - do well or right } \\
\text { - act in the right way } \\
\text { - more beautiful } \\
\text { - (comparative of good) of a more } \\
\text { excellent kind; (of health) recovering } \\
\text { from illness, contrasted with ill and } \\
\text { related to well } \\
\text { - lovelier, better } \\
\text { - comparative adjective of lovely } \\
\text { - comparative degree of nice } \\
\text { - best or most favorable, especially } \\
\text { under a particular set } \\
\text { circumstances of } \\
\text { - best or most favorable, especially } \\
\text { under a particular set } \\
\text { circumstances of } \\
\text { be charitable (to); be nice (to); do a } \\
\text { favor (for); do a good turn (for); do } \\
\text { good (to); friendly (to); give alms } \\
\text { (to); give charity (to); kind (to); } \\
\text { philanthropize; treat with kindness } \\
\text { optimal; optimum; the best; the } \\
\text { finest; the most beautiful; the most } \\
\text { splendid; the nicest } \\
\text { better (than); preferable } \\
\text { superior (to) } \\
\text { aid; assist; be charitable to; be } \\
\text { devoted; to be/do good to sb/sth; be } \\
\text { dutiful; be faithful; be honored; be }\end{array}$ \\
\hline
\end{tabular}

Arab World English Journal for Translation \& Literary Studies 


\begin{tabular}{|c|c|c|c|}
\hline & & & $\begin{array}{l}\text { kind; be obedient to; be obey; be } \\
\text { pious; be revere; be reverent; be } \\
\text { treated with reverence or kindness; } \\
\text { be true; be venerate; confer a benefit } \\
\text { upon; do a favor for; do good to; } \\
\text { favor; help; oblige; relieve; support }\end{array}$ \\
\hline 5. & Ijazah & $\begin{array}{l}\text { MY-EN: Completed and endowed } \\
\text { a degree - Graduate, postgraduate, } \\
\text { doctorate, baccalaureate, } \\
\text { MY-AR: شهادة جامعية } \\
\text { MY-MY: surat akuan sbg tanda } \\
\text { lulus atau tanda tamat belajar dari } \\
\text { sesebuah universiti: } \\
\begin{array}{l}2 \text { kebenaran untuk melakukan } \\
\text { sesuatu; izin; ijazah; berijazah } \\
\text { mempunyai sudah } \\
\text { mendapat ijazah. }\end{array}\end{array}$ & $\begin{array}{l}\text { AR-EN: \{Study\} Leave i.e., holiday } \\
\text { Verb: allow } \\
\text { - permit to do something or to go in, } \\
\text { let something be done or happen, let } \\
\text { somebody have something } \\
\text { - say or show or feel that somebody } \\
\text { or something is good or acceptable } \\
\text { or satisfactory; confirm, accept } \\
\text { something; advocate; admire; praise; } \\
\text { consent to } \\
\text { - to express formal approval for } \\
\text { someone or something } \\
\text { - give permission for something; } \\
\text { allow } \\
\text { - to make lawful; bring into harmony } \\
\text { with the law } \\
\text { - to make legitimate by decree, etc. } \\
\text { - to allow to, not prevent; cause to } \\
\text { - to grant a license to or authorize the } \\
\text { use of } \\
\text { - give permission to } \\
\text { - serve as a warrant for; justify; } \\
\text { guarantee or attest to the genuineness } \\
\text { of an article, the worth of a person, } \\
\text { etc. } \\
\text { - allow the possibility of something; } \\
\text { leave room for something } \\
\text { - gain belief or influence for } \\
\text { Entitled } \\
\text { justify; make permissible or lawful }\end{array}$ \\
\hline 6. & Ikrar & $\begin{array}{l}\text { MY-EN: Vow, affirmation } \\
\text { MY-AR: قسم/عهد } \\
\text { MY-MY: janji yg sungguh- } \\
\text { sungguh; janji yg disertai sumpah; } \\
\text { pengakuan } \\
\text { Ar 1. lafaz janji, }\end{array}$ & $\begin{array}{l}\text { AR-EN: declaration \{of weight } \\
\text { acknowledge; admit; allow; avow; } \\
\text { concede; confess; grant; own; } \\
\text { recognize } \\
\text { adopt; approbate; approve; assent to; } \\
\text { confirm; consent to; endorse; } \\
\text { maintain; pass; ratify; sanction; }\end{array}$ \\
\hline
\end{tabular}




\begin{tabular}{|c|c|c|c|}
\hline & & $\begin{array}{l}\text { 2. janji yg sungguh-sungguh, } \\
\text { biasanya disertai dgn sumpah, } \\
\text { pengakuan } \\
\text { 3. ark piagam: Pertubuhan } \\
\text { Bangsa-Bangsa Bersatu; berikrar } \\
\text { berjanji dgn sungguh-sungguh hati } \\
\text { secara lisan }\end{array}$ & $\begin{array}{l}\text { subscribe to; sustain; uphold; } \\
\text { validate } \\
\text { affirm; confirm; establish } \\
\text { consolidate, to make or become solid } \\
\text { or strong } \\
\text { establish; fix; settle; stabilize } \\
\text { adopt } \\
\text { approbated; approved; authorized; } \\
\text { confirmed; sanctioned } \\
\text { be adopted; be affirmed; be } \\
\text { approbated; be approved; be } \\
\text { conclusive; be confirmed; be } \\
\text { decisive; be endorsed; be final; be } \\
\text { irreversible; be irrevocable; be } \\
\text { legalized; be maintained; be passed; } \\
\text { be ratified; be sanctioned; be } \\
\text { sustained; be upheld; be validated } \\
\text { - acknowledge; admit; adopt; allow; } \\
\text { approbate; approve; assent to; attest } \\
\text { (to); authenticate; certify; concede; } \\
\text { confirm; consent to; endorse; grant; } \\
\text { legalize; maintain; pass; ratify; } \\
\text { sanction; subscribe to; sustain; } \\
\text { uphold; validate; verify } \\
\text { - approve; confirm; endorse; pass; } \\
\text { sanction; uphold; validate }\end{array}$ \\
\hline 7. & Insaf & $\begin{array}{l}\text { MY-EN: Regret, Remorse, } \\
\text { Chasten, penitent } \\
\text { MY-AR: ندامة } \\
\text { MY-MY: } \\
\text { - dpt memahami sesuatu perkara } \\
\text { sehingga memperoleh kesedaran } \\
\text { Sesal - sedar } \\
\text { - perasaan tidak senang dsb kerana } \\
\text { telah melakukan sesuatu yg salah } \\
\text { dll.; perasaan insaf setelah } \\
\text { membuat kesalahan. } \\
\text { - menyesal berasa dukacita atau } \\
\text { ralat kerana melakukan kejahatan } \\
\text { dll; } \\
\text { - berasa insaf: sesuatu yg disesali }\end{array}$ & $\begin{array}{l}\text { AR-EN: Equity, Fairness, Justice } \\
\text { [General] } \\
\text { be just with; do justice to; establish } \\
\text { someone's right; right; treat fairly; } \\
\text { treat with justice } \\
\text { - treat fairly } \\
\text { - retune itself or something to a } \\
\text { proper, correct, upright position, or } \\
\text { correct itself or something } \\
\text { - do justice to } \\
\text { - treat with justice; be just with } \\
\text { - be give a just judgment; be just } \\
\text { - treat fairly }\end{array}$ \\
\hline 8. & Jenazah & $\begin{array}{l}\text { MY-EN: bier } \\
\text { MY-AR: الميت، الجثة } \\
\text { MY-MY: jasad orang mati; mayat }\end{array}$ & $\begin{array}{l}\text { AR-EN: the carrier of the corpse } \\
\text { brings it to the grave for burial } \\
\text { - part of the ceremony for a funeral }\end{array}$ \\
\hline
\end{tabular}

Arab World English Journal for Translation \& Literary Studies 
AWEJ for Translation \& Literary Studies Volume, 5 Number 4. October 2021

\begin{tabular}{|c|c|c|c|}
\hline & & Ar: mayat (bagi orang Islam) & $\begin{array}{l}\text { - burial ceremony } \\
\text { - the burial of a dead person with its } \\
\text { ceremonies; a burial procession or } \\
\text { service } \\
\text { - the burial procession } \\
\text { - a funeral or funeral rites }\end{array}$ \\
\hline 9. & Khalifah & $\begin{array}{l}\text { MY-AR: Caliph, caliphate, } \\
\text { Sayyidina } \\
\text { MY-AR: الخليفة السياسية، الملكية } \\
\text { MY-MY: } \\
\text { Ar: tuan kami (biasanya panggilan } \\
\text { utk Nabi Muhammad SAW serta } \\
\text { khalifah-khalifah Ar-Rasyidin } \\
\text { pengganti Nabi Muhammad s.a.w.; } \\
\text { gelaran bagi ketua agama atau raja } \\
\text { yg memerintah di beberapa buah } \\
\text { negara Islam }\end{array}$ & $\begin{array}{l}\text { AR-EN: successor - heir or } \\
\text { following } \\
\text { Khaleefah } \\
\text { In the beginning, it was a reference } \\
\text { to the successor of the Prophet. Later } \\
\text { on, it began to take on the meaning } \\
\text { of the head of state for a Muslim } \\
\text { nation. } \\
\text { replacement } \\
\text { - person or thing that replaces } \\
\text { another } \\
\text { - descendant } \\
\text { - member of a country's reserve } \\
\text { forces } \\
\text { - a spare part; duplicate } \\
\text { - substitute; alternate } \\
\text { - substituent } \\
\text { - a person who studies another's role } \\
\text { or duties in order to act at short } \\
\text { notice in the absence of the other } \\
\text { - person taking over or following } \\
\text { after another's turn of duty } \\
\text { - used instead of the one that was } \\
\text { intended to be used } \\
\text { Abandon } \\
\text { appoint as a successor } \\
\text { substituted for - dispossess and take } \\
\text { the place of children } \\
\text { - plural of child } \\
\text { - descendant } \\
\text { - progeny: offspring: posterity } \\
\text { - child or children of a particular } \\
\text { person or couple, or young of an } \\
\text { animal } \\
\text { - people who will live after you are } \\
\text { dead } \\
\text { - offspring } \\
\text { backward; back foremost }\end{array}$ \\
\hline
\end{tabular}

Arab World English Journal for Translation \& Literary Studies 


\begin{tabular}{|c|c|c|c|}
\hline & & & $\begin{array}{l}\text { - situated behind } \\
\text { - to the rear of; not having made so } \\
\text { much progress as; remaining after; in } \\
\text { the past; the cause of or explanation } \\
\text { for } \\
\text { - back, rear-end or hinder part of } \\
\text { something } \\
\text { - at the back of something }\end{array}$ \\
\hline 10. & Khalwat & $\begin{array}{l}\text { MY-EN: fornicate/adultery in } \\
\text { secluded place - involved in illegal } \\
\text { sexual acts according to Islam } \\
\text { MY-AR: }{ }^{\prime} \text { j } \\
\text { MY-MY: berada berdua-duaan } \\
\text { (bukan suami isteri yang halal } \\
\text { hubungan) dlm keadaan yg } \\
\text { sumbang di tempat yg terpencil } \\
\text { atau tersembunyi }\end{array}$ & $\begin{array}{l}\text { AR-EN: } \\
\text { conclave } \\
\text { - private or secret meeting } \\
\text { - meeting restricted to particular } \\
\text { people, whose outcome should be } \\
\text { secret } \\
\text { aloneness } \\
\text { - loneliness; singleness } \\
\text { - act of putting someone in a room, } \\
\text { prison, etc., or the state of being } \\
\text { there } \\
\text { - seclusion, act of isolating or being } \\
\text { isolated } \\
\text { - state of being completely alone } \\
\text { - state of being alone without } \\
\text { companions } \\
\text { - the state of being able to be alone } \\
\text { - the act of being reclusive } \\
\text { - retiring or being retired } \\
\text { - secluding or being excluded } \\
\text { - the state of being alone } \\
\text { - loneliness; soleness } \\
\text { - act or instance of uniting or being } \\
\text { united } \\
\text { - withdrawal into privacy or } \\
\text { seclusion, or a secluded place } \\
\text { hermitage } \\
\text { - a hermit's dwelling; a solitary } \\
\text { dwelling } \\
\text { - place of privacy } \\
\text { - isolation, loneliness, loneness, } \\
\text { privacy, seclusion, solitude }\end{array}$ \\
\hline 11. & Malu & $\begin{array}{l}\text { MY-EN: Coy, shy } \\
\text { MY-AR: حياء/خجل/استحياء/مستحي/ة: Segan } \\
\text { MY-MY: }\end{array}$ & $\begin{array}{l}\text { AR-EN: } \\
\text { ماله - [colloq. utter: mā-lu]: } \\
\text { i.e., "What's wrong with him?" } \\
\text { Standard: [utter] Ma lahu }\end{array}$ \\
\hline
\end{tabular}

Arab World English Journal for Translation \& Literary Studies 
AWEJ for Translation \& Literary Studies Volume, 5 Number 4. October 2021

\begin{tabular}{|c|c|c|c|}
\hline 12. & Marah & $\begin{array}{l}\text { MY-EN: anger, angry } \\
\text { MY-AR: غضب } \\
\text { MY-MY: meradang, baran }\end{array}$ & 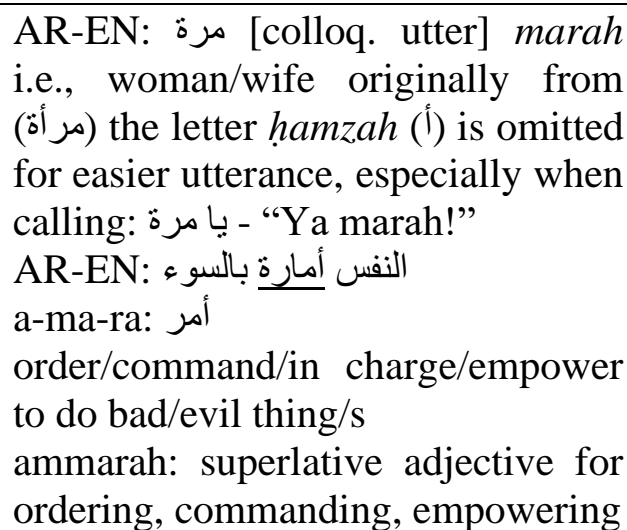 \\
\hline 13. & Muslihat & $\begin{array}{l}\text { MY-EN: Trickery, deception, } \\
\text { Machiavellian } \\
\text { MY-AR: خداع، مكيدة } \\
\text { My-MY: tipu, jerat }\end{array}$ & $\begin{array}{l}\text { AR-EN: adjuster (for plural feminine } \\
+(\text { ) } \\
\text { - person who fixes, regulates } \\
\text { something or reconciles and settles } \\
\text { disputes } \\
\text { - person who seeks reconciliation } \\
\text { (between conflicting parties) } \\
\text { - person who tries to get people to } \\
\text { agree } \\
\text { - person who corrects or points out } \\
\text { faults } \\
\text { - a person pointing out mistakes and } \\
\text { correcting them } \\
\text { - person who causes people to } \\
\text { become friends again after any } \\
\text { quarrel } \\
\text { - a person who has a reformational } \\
\text { tendency } \\
\text { - one who reforms } \\
\text { Adjuster, conciliator, corrector, } \\
\text { amender, fixer, } \\
\text { peacemaker, reconciler, rectifier, } \\
\text { reformer, reformist, repairer }\end{array}$ \\
\hline 14. & Nakal & $\begin{array}{l}\text { MY-EN: Naughty, mischief } \\
\text { MY-AR: مشّاغبة } \\
\text { MY-MY: 1. suka melakukan } \\
\text { sesuatu yg dilarang spt } \\
\text { mengganggu dll. (terutama kanak- } \\
\text { kanak), tidak menurut kata: } \\
\text { 2. buruk kelakuannya, jahat }\end{array}$ & $\begin{array}{l}\text { AR-EN: exemplary punishment } \\
\text { - make an example of; punish } \\
\text { severely; torture } \\
\text { abstain from; desist from; forbear; } \\
\text { refrain from; refuse; stop } \\
\text { chain; fetter; shackle; tie } \\
\text { make an example of; punish } \\
\text { severely; torture } \\
\text { draw back from; flinch; recoil from; } \\
\text { shirk; shrink from }\end{array}$ \\
\hline
\end{tabular}

Arab World English Journal for Translation \& Literary Studies 
AWEJ for Translation \& Literary Studies Volume, 5 Number 4. October 2021

\begin{tabular}{|c|c|c|c|}
\hline & & & a deterrent punishment \\
\hline 18. & Rogol & $\begin{array}{l}\text { MY-EN: Rape } \\
\text { MY-AR: الاغتصاب } \\
\text { MY-MY: perbuatan memperkosa } \\
\text { atau mencabul kehormatan } \\
\text { perempuan: berlakulah perkara- } \\
\text { perkara sumbang spt dan zina; } \\
\text { merogol, memperkosa atau } \\
\text { mencabul kehormatan perempuan: } \\
\text { kesalahan spt menipu, , dsb } \\
\text { adalah menjadi kesalahan jenayah; }\end{array}$ & $\begin{array}{l}\text { AR-EN: man; one; person; bloke; } \\
\text { fellow }\end{array}$ \\
\hline 15 . & Sakit & $\begin{array}{l}\text { MY-EN: Ache, ill, growing pains, } \\
\text { pain, sick, sore, sicken } \\
\text { MY-AR: مريض، عليل } \\
\text { MY-MY: Sengal } \\
\text { Berpenyakitan } \\
\text { Berasa sakit/tidak sihat }\end{array}$ & $\begin{array}{l}\text { AR-EN: mum } \\
\text { - silent; quiet } \\
\text { - not speaking or refusing to speak; } \\
\text { silent } \\
\text { - silent; making no avoidable noise } \\
\text { - not speaking; nor uttering } \\
\text { - silent; speechless; wordless } \\
\text { - dumb, mute, speechless } \\
\text { - without a word } \\
\text { - silent; sulky } \\
\text { - silent; quiet } \\
\text { Noiseless, quiet, silent, soundless, } \\
\text { speechless, voiceless, wordless }\end{array}$ \\
\hline 16. & Sejarah & $\begin{array}{l}\text { MY-EN: history } \\
\text { MY-AR: تاريخ } \\
\text { MY-MY: 1. sl asal usul } \\
\text { (keturunan), salasilah: Melayu; } \\
2 . \text { peristiwa yg benar-benar } \\
\text { berlaku pd waktu yg lampau, } \\
\text { kisah, riwayat, tambo: 3. = ilmu } \\
\text { kajian atau pengetahuan mengenai } \\
\text { peristiwa-peristiwa yg telah lalu, } \\
\text { tawarikh: Tanah Melayu; ahli } \sim \\
\sim \text { umum sejarah mengenai seluruh } \\
\text { dunia; bersejarah } \\
\text { Dalam konteks sastera lama } \\
\text { bersinonim dengan asal usul, } \\
\text { salasilah, asal keturunan, susur- } \\
\text { galur, asal-usul, surih-surih, titisan } \\
\text { darah, silah-silah, kisah, riwayat, } \\
\text { tambo, tawarikh, babad, teromba }\end{array}$ & $\begin{array}{l}\text { AR-EN: } \\
\text { Shajārah: tree - a very tall plant that } \\
\text { has a wooden trunk, branches, and } \\
\text { leaves } \\
\text { arbor; tree } \\
\text { Shä-jara - mushājarah - Shijārr+ah: } \\
\text { - dispute noisily with; quarrel; fight } \\
\text { - argue noisily with } \\
\text { - argue or quarrel with } \\
\text { altercate with; argue noisily with; } \\
\text { argue with; battle against; bicker } \\
\text { with; brawl with; combat; dispute } \\
\text { with; fight (with); fight with; hassle } \\
\text { with; jangle with; pick a quarrel } \\
\text { with; quarrel with; scrimmage; } \\
\text { skirmish; spat with; squabble with; } \\
\text { start a brawl with; wrangle with } \\
\text { by closer to sound - sijārah: }\end{array}$ \\
\hline
\end{tabular}

Arab World English Journal for Translation \& Literary Studies 
AWEJ for Translation \& Literary Studies Volume, 5 Number 4. October 2021

\begin{tabular}{|c|c|c|c|}
\hline & & & $\begin{array}{l}\text { cigarette - roll of shredded tobacco } \\
\text { enclosed in thin paper for smoking }\end{array}$ \\
\hline 17. & Tertib & $\begin{array}{l}\text { MY-EN: Gentlemanly, prim, } \\
\text { decorous: } \\
\text { MY-AR: نظخلق/منأد } \\
\text { MY-MY: sopan-santun } \\
\text { Tata tertib } \\
\text { MY-EN: system, rule, turn } \\
\text { MY-AR: } \\
\text { MY-MY: } \\
\text { 1. Peraturan, aturan atau giliran } \\
\text { unsur dalam suatu siri yang } \\
\text { tersusun. } \\
\text { 2. Pemberat atau kepentingan yang } \\
\text { diberikan kepada suatu kedudukan } \\
\text { dalam sistem. } \\
\text { 3. Bentuk suatu fungsi matematik. }\end{array}$ & 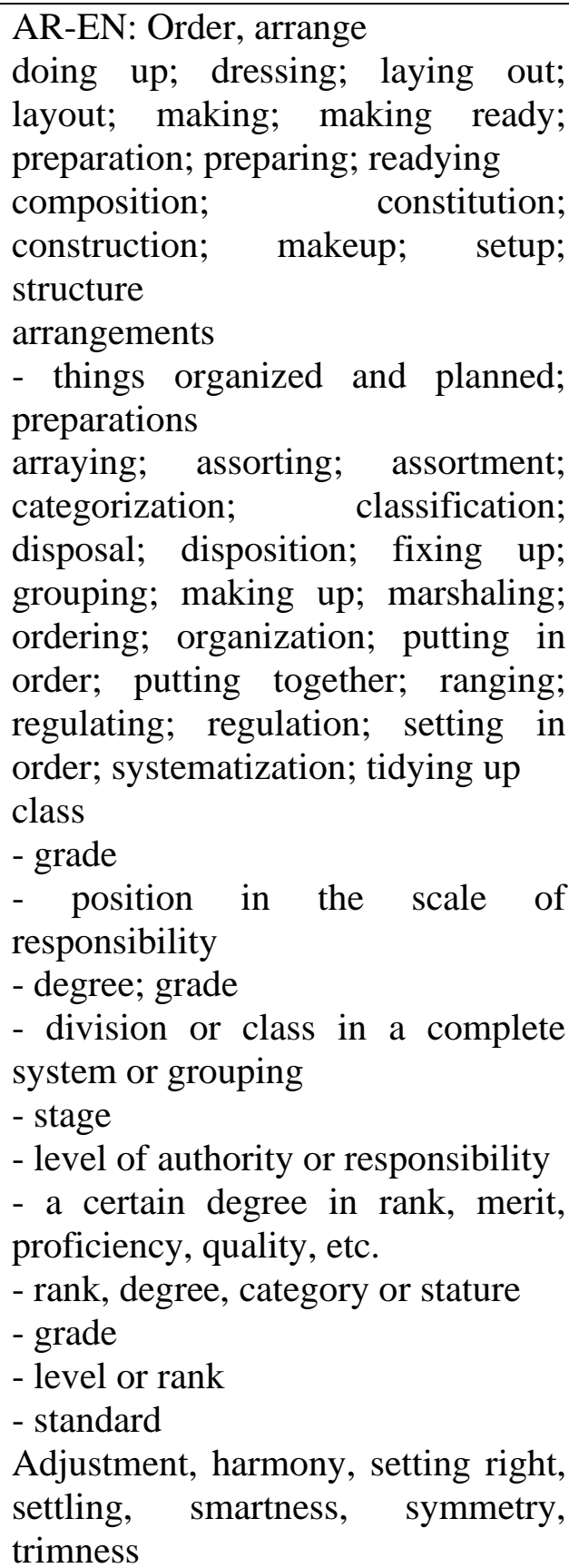 \\
\hline
\end{tabular}

\section{Discussion}

There are many words originated from the Arabic language (AR) in the Malay language (MY) as studied in (Noor Azlina Zaidan et al., 2015). Most of them maintain the original meaning as they are in the Arabic language like the words: abad, akad, kitab, aman, and salam. However, 
some words surprisingly, their meaning 'diverge' from the meaning in the Arabic language either partially or fully. The selected words in Table 1 serve the purpose to show there is difference of meaning and definition in the usage between the two languages.

The word fitnah, hasrat, ijazah, ikrar, insaf, malu, marah, muslihat, nakal, and sakit in the Malay language have no direct relation with the meaning of the homonymous words in the Arabic language. Anyhow, we can consider distant indirect relation of meaning between the languages for fitnah and ijazah as a result of the actual meaning in the Arabic language i.e., slander causes affliction or slander is a trial and got degree (ijazah) permits someone to do something as a person who knew the field or to get a job. However, other than the two words, it is difficult to imagine any relation between the two languages and how they reached the present meanings.

Simply relating, in the sample case of borrowings from the Arabic language, when Arabic nouns are integrated into the recipient language together with the article al-/ال/; this demonstrates that the people who took over these elements did not fully master the foreign language (Versteegh, 2001, p.479) as it may include the meaning of 'the'. Thus, a contemplative effort gave a connotation of misunderstanding occurred to the speakers of the recipient language when the words were first introduced to them. It seemed like a trial to communicate in the Arabic language where a situation imagined that it was useless to talk with the Arabs in the recipient local language due to the very low mastery of bilingualism of the Malay-Arabic languages among the Arabs. It is known that previously, the Arabs themselves were barely ever bilingual and it was impossible to contribute transmitting loanwords (Versteegh, 2001, p.490).

This phenomenon was already being explained by linguists that it happened when the level of bilingual mastery is inadequate to grasp the correct meaning from the donor language speakers. In another word, the recipient language speakers had inaccurately guessed or assumed the meanings of the words they were in contact usually by listening as the accuracy is very poor due to lack of systematic borrowing processes, unlike via reading by fully develop bilingual mastery professional like religious scholarly clerics (Versteegh, 2001, p.476). There is an inverse correlation between level of loanwords integration and degree of bilingual mastery - the more speakers or hearers master the donor language the more they borrow words in unadapted form (Thomason \& Kaufman, 1988, p.33).

Return back to our sampled words, the word ' $f$ itnah' is mainly meant as trial or test in AR rather than slander or mockery in MY, maybe it was being misunderstood when being explained by an Arabian scholar with limited Malay language fluency when interpreting the Qur'anic verse or Malay students wrongly guessed the meaning of the Arabic word when heard it being explained it could be he concluded it from an example of test is slander actually what the scholar wanted to convey for: "walfitnatu ashaddu minal qatli" (Q2: 191) and "walfitnatu akbaru minal qatli" (Q2:217) as fitnah here meant "persecution" in Mustafa Khattab's translation i.e., hostility and illtreatment, especially of racism or political or religious beliefs; oppression (zulm), victimization, abuse, torture, persistent annoyance or harassment, systematic mistreatment of an individual of a group by another individual or group" (English translation of The Clear Qur'an). Exegetically, Ibnu Kathīr and al-Qurțubī interpreted it: "The test of being involved in the blasphemy (al-kufr) 
AWEJ for Translation \& Literary Studies Volume, 5 Number 4. October 2021

or polytheism (al-shirk) is worse than the test to involve in war/killing (al-qatl)" (El-Helw et al., 2017).

About similar divergence happened to hasrat, which AR meant for 'grief' unlike in MY turns positively to wish, desire, hope or intend. As well as ijazah, became certificate in MY instead of holiday in AR. Meanwhile, ikrar is used as oath or vow in MY unlike it is meant as confession or acknowledgment in AR. MY insaf diverges too much from AR that means justice turns into regret and remorse in MY. Seriously regretful, these distorted meanings are related to the translation of words exist in the Holy Qur'an or Hadith, yet, the main criterion of permissible interpretation that is agreed among exegetes since the beginning of the advent of Islam is it has to be fully coherent with the literal meaning in the Arabic language first and foremost; and then, as per explained by the Qur'an itself elsewhere, next, as per stated by verified accepted Hadith or guided opinions of the Prophet's companions. Or else it will be categorized as deviant or heretic teachings as the meanings turn out misleading to the readers (Ammar bin Fadzil, 2011, pp.183-184), especially whose bilingual mastery are zero like monolinguals or low level of mastery bilinguals who do not reach confident level with their knowledge of the Arabic language yet.

It is a little bit different in the case of malu and marah where both are assumed to be adapted from spoken (colloq.) words being heard with mistaken meaning understood. Malu is shy or bashful in MY, which in AR means: "What is wrong with him?" Like marah, maybe an Arabian husband was angry to his wife and shouting: "Ya marah...ya marah!" repetitively and then the Malay spectators were guessing afar that it was meant for the angry acts without verifying it. Albeit, actually 'marah' is shortened from 'mar'ah' (i.e., woman) for dialect utterance. Here, the letter 'hamzah' in the middle of the word in the standard Arabic language disappeared to make it easier to utter in the spoken Arabic language/dialect (al- $\left.{ }^{\complement} \overline{a m m} \overline{1}\right)$. It is widely used among Arabs to call their wife so. Even the wife of somebody is addressed as Marat [+her husband's name] to mean wife of that guy.

However, regarding conferring marah to relate the Qur'anic verse (Q12:53) like the researcher was being asked is also inappropriate to the meaning, as MY nafsu amarah is not equally meant 'anger' in AR, which is 'ghadab'. It is again more like being guessed then used in adapted form without verification again. The actual Qur'anic wording is "inna al-nafsa la-ammāratun bissü", which literally means: "indeed the soul is always commanding self towards doing evil". Ammārah is in the superlative form of adjective for commanding, signifies intensity of action. Although being angry is also considered incited by evil spirit in Islam, but it does not confine to only that.

The misunderstanding of the adapted loanwords lingered in muslihat, nakal, and sakit. Muslihat is used as trick or deception in MY instead of plural for feminine fixers based on AR doers form. As much as nakal is implied as naughty in MY whereby it means preventive punishment in the Arabic language as used within the Qur'anic verse related to theft hudud laws (Q5: 38). Sakit in MY simply means in sick/hurt/pain or painful where it has confused Arabian students studying in Malaysia when asked by a Malay doctor mentioning the word 'sakit' for pain being confused with AR sākit, which means: a silent person [in a doer form: ism $\left.f \bar{a}^{c} i l\right]$.

Arab World English Journal for Translation \& Literary Studies 
The inadequate level of bilingual mastery to accurately translate is also obviously low for the rest of the words but relatively indicate some level of higher understanding of the words or guessing their meaning: tertib, sejarah, ihsan, khalifah, jenazah, and had/hudud - which are arranged from lower to higher degree of similarity to the meaning in the Arabic language. Tertib is originally tartīb in AR mainly means order and arrangement rather than politeness in MY meaning or discipline when combined like this: tata tertib.

But sejarah in MY is more confusing in AR, as there is the AR word 'tarikh' that usually means date [i.e., DD/MM/YY] but also 'history' instead of AR shajarat that means a 'tree', which likened the word 'family tree' as if got interfered with English translation of 'silsilat/saläsilat' to family tree to shajarah as a tree. Even if assumed from sijärat, a closer sound of utterance to sejarah, the meaning turns funnier as it is called for cigarette in AR. What cigarette has to do with history? Or a more logical interpretation could be it was originated from AR shijārat i.e., a fight or quarrel when it was narrated, they thought the AR word shijärat means 'history' - also deviates from original meaning in the donor language.

It turns less than other words for 'ihsan', as spokenly it mainly means more for 'belas ihsan': sympathize - more attuned into the doing good meaning it has in AR, although still, not exactly congruous too. Similarly happened to jenazah, which correctly related to burial ceremony although specifically in the spoken meaning it signifies the corpse carrier to the burial place in AR but inaccurately used in spoken MY specifically meant for the corpse of the deceased instead. Again, we can assume inaccurate guessing had occurred to the ones who had adapted the loanword into MY. The AR meaning had not reached the recipient language speakers' capability to fully grasp the actual meaning, which is in synch with the theory of level of bilingual capability that will determine the accurate adoption of the loanword's utterance together with their meaning in the donor language.

Like the words khalifah and had/hudud, which are more restricted to function as religiousrelated terms where the meanings partially share the AR meanings but the MY meaning confined only for the historical political caliph in khalifah although its AR meaning varies as in the Table 1 like descendants, children, successor or offspring or repetitively being succeeded by other human generations (Noble Quran, 2020). Even the verbal derivative khallafa is used to ask about 'giving birth' in the spoken Jordanian Arabic dialect: "Hal khallafti?" i.e., "Did you already give birth?" to logically relate with the AR meaning of children or offspring.

Ironically, the AR had/hudud are derivatives of the exact AR verbal origin: hadda, where had as its noun is singular for limit that turns hudud its plural form. However, MY usage restricts had to mean: limit/ed and separate the hudud to mean the Islamic law ordained by Allah in the Qur'an onto the crimes of theft, drinking liquor, murder, fornication, adultery, etc., by terming them: 'hukum hudud'. AR hudud may mean borders and boundaries as well as had can be meant for 1 type of the law of those crimes or generally for the whole law in entirety or a limitation or as singular form of border and boundary. 
AWEJ for Translation \& Literary Studies Volume, 5 Number 4. October 2021

There are other MY words that have connotation of misleading meaning from the spoken Arabic dialects heard, for instance the word: 'rogol', which means 'rape' may originate from the spoken Egyptian Arabic dialect for ' $r o j u l$ ': man/guy that is uttered as 'rogol' in their dialect where the letter 'jim' (ج) becomes ' $g a$ ' (अ) ( $)$. The AR speaker might have mentioned it to alert the presence of the rapist who was usually a guy rather than implying the meaning of 'raper' directly, which is 'mughtasib' in the standard AR. In fact, it is very rare for AR speakers to talk in the standard Arabic language in their daily speech. Most of them are usually even not so familiar or unable to talk in standard AR, unless, in a formal setting like reading a textbook in a school or similarly at work, e.g., professional interpreter.

Finally, the linguist researcher who is an Arabic native speaker endorsed that there IS evident divergent meaning in the usage of those words both in AR and MY languages, respectively. They are loanwords from the Arabic language that are partially adopted but mostly adapted fitting to the point of view of the Malays who historically had introduced the words with such accepted meaning in the recipient language (Haugen, 1950; Saussure, 2001).

\section{Observations}

The linguist researcher observed that generally the Arabic loanwords in the Malay language can be categorized as below:

1. Some words are being adopted, which simply carry the same meaning as in the Arabic language for example: 'abad', 'Ahad', akad nikah', 'himar', 'haram', 'halal', and 'wasiat' - the majority is related to the semantic field of religion.

2. Some words are also being adopted, which by the meaning found in the dictionary has the same meaning in both the Malay and the Arabic languages like 'jenazah', as 'of the ceremony for a funeral'. However, their meaning differs in spoken languages where it becomes the corpse of the deceased (MY) and the carrier of the deceased when hold by humans to be brought for the burial (AR). Yet, the main theme is there.

3. Some words are being adapted where meaning regards; the MY meaning is different and irrelevant than in the AR, for instance: 'hasrat' means 'wish and desire' in the Malay language but means 'regret and become sad' in Arabic. It has connotation of inaccurate guess/grasp of meaning when first introduced to the recipient language but accepted, later, nativized. Most linguists inferred this phenomenon due to low level of bilingualism among the speakers of the recipient language with the pairing donor language.

4. Some words that have restricted meaning are actually derivatives of the same verbal origin but were applied different meaning respectively as if they are not related like 'had' and ' $h u d u d$ ', which, in MY means 'limit' like 'had laju' for 'speed limit' and a type of Islamic criminal law i.e., 'hukum hudud' (hudud law).

5. Some words are somehow are used for the same meaning in both languages only it has diverse meanings for multiple usage in AR compared to its restricted meaning and usage in MY for example: 'khalifah' has only one meaning in the Malay language which is 'caliph'. On the other hand, it has many meanings in AR as shown in Table 1.

After analyzing the loanwords, it shows that borrowing happened mainly out of necessity for the Malay language to enrich its semantic field of religion (Sapir, 1921) i.e., Islam where the source 
of language is the Arabic language, especially it is the language of the Holy Qur'an and the Prophetic Tradition (Hadith) as the primary sources of reference for everything in life, especially in worshipping and ritual. Apart from that, Ricquier (2019, p.3) had similarly observed that it also permeates into language into the semantic fields of jurisprudence, trade, and maritime affairs like astronomical terms using extralinguistic evidence.

Additional, according to McMahon (1994, p.204) in order for native speakers of a recipient language to be the agents of this specific kind of change (borrowing), they must have some kind of knowledge of the donor language as the source of borrowing, either they got to learn it through formal education or acquire it in a real encounter with the group of foreign people for the language contact to occur. In other words, even if the lexical borrowing requires only very limited bilingual mastery, the local recipient speakers involved must have developed it to some degree.

The most critical is the divergent meaning occurrences; it is related to the issue of understanding the Islamic primarily referred sources: the Qur'an and the Sunnah as they are originally in the Arabic language as well as its sciences references were written in the Arabic language as it will lead to incorrect understanding to the Malays and confusion to the Arabic native speakers who mingle with the Malays (but due to limited bilingual mastery (or seriously even zero) are unable to detect/sense that the translated meaning of the same sound word is different in the Malay usage). Thus, we suggest for the relevant linguists to further study these transformations that the meaning of these words had historically underwent across time, so, then they can differentiate between 'adopted' and 'adapted Arabic' loanwords within the Malay language for the public to refer whether or not a Malay word got same meaning or divergent meaning with homonymous Arabic words and to list the correct meaning from the original donor language: the Arabic language for the Malay users' reference.

It is a need for the Muslim Malays to be cautious in understanding similar sounded words in both languages for both languages speakers who are exposed to the usage without adequate bilingual mastery level to comprehend the correct meaning of such words in each language that it may be divergent with each other in spite of the shared sound. There should be an awareness on this phenomenon as it will compromise the accurate meaning/s of understanding the Qur'an, the Hadith, the Islamic Jurisprudence (Fiqh); etc. This is very critical that such words must be corrected to the original meaning of the donor language: the Arabic language, especially if it is related to the Islamic Creed (Aqidah) until the awareness leads to a proactive initiative to correct the meaning at national level usage like it is practiced for English language at higher sensitivity, albeit, the Arabic language is more associated with the official religion of the country.

\section{Conclusion:}

However, it is known in the linguistics that in most cases, the historical context where borrowing had taken place, is difficult to be identified or discovered that it is impossible to investigate how it was developed (Versteegh, 2001, p.502). The dilemma appears when linguistic needs that are intertwined with the usage of faith (Islam) and identity (Malay) (Nurul-ikhlas Arshad \& Mohamed Ismail Ahamad Shah, 2014), which one is to defend more?

Arab World English Journal for Translation \& Literary Studies 
In reality, borrowing phenomenon will not happen to the native speakers of a recipient language - according to McMahon (1994), unless, familiarity is taken into account for another crucial factor because the more familiar the recipient language with the donor language; the more the speakers borrow from it by 'adopting' it rather than 'adapting' the borrowed words of the donor language although taken from document or any media in that language that exposed to them. Hence, it is not unusual to end up with divergent or misleading meaning, away from the original meaning of the donor (i.e., Arabic) language due to insufficient bilingual mastery level but under cultural pressure for instance, out of prestigious style for social advancement had them being absorbed into the local usage without being verified first. Higa (1979, p.284) had perceptively concluded: "this phenomenon (adopt vs. adapt) reveals that; intellectuals tend to borrow foreign words through the eye, while others borrow through the ear".

While Weinreich (1968, p.11) described it like:

"In speech, interference is like sand carried by a stream; in language, it is the sedimented sand deposited on the bottom of a lake. In speech, it occurs anew in the utterances of the bilingual speaker as a result of his personal knowledge of the other tongue. In language, we find interference phenomena which, having frequently occurred in the speech of bilinguals, have become habitualized and established. Their use is no longer dependent on bilingualism."

He further (1968, pp.47-51) listed that it is among how the donor language influences the recipient language in either these three (3) ways in the case of loanwords:

1) Confusion in usage as appeared in divergent meaning loanwords: e.g. fitnah.

2) Disappearance of the old word/term (as the word AR: solat vs. MY: 'sembahyang' originally 'sembah Hiyang' - 'Hiyang' is a god of the Nusantara (Abdul Malik Karim Amrullah (HAMKA), 2015), which is considered polytheistically sinful at creed level in Islam to stay using this word for Islamic prayer.

3) Survival of both the new and old word, with a specialization in content like 'syurga' [originally from the Sanskrit language] and Jannah (AR), which both mean paradise/heavens.

According to Ricquier (2019), this kind of research actually supposed to be done by linguists using more detailed data from fieldwork to avoid drawbacks, which could be overcome by following the principles of comparative linguistics method and making thorough correspondences by looking at a broader sample of vocabulary. But this suggestion will lengthen the research process to reach suffice available comparative data from the languages being studied. However, due to lack of expertise and time constraint, this preliminary study also relied on the available literature in order to highlight the matter to the relevant researchers of the more relevant fields to properly deal with this issue soon.

\section{About the Authors:}

Nur Afifah binti Abas is a postgraduate student of the Humanities School at the Universiti Sains Malaysia. She is a Malaysian living in Najran, Saudi Arabia where later she met Alia: the validating peer debriefer. She previously graduated in Islamic Revealed Knowledge and Heritage 
AWEJ for Translation \& Literary Studies Volume, 5 Number 4. October 2021

at MA and BA levels from the International Islamic University Malaysia (IIUM). https://orcid.org/0000-0001-7087-4908

Dr. Mohd Nizam bin Sahad is an associate professor of the Islamic Studies Section, the School of Humanities at the Universiti Sains Malaysia. He previously graduated his Ph.D. from the Universiti Malaya (UM) in Malaysia in the Fundamentals of Religion (Usuluddin). His research interests are related to Islamic Creed (Aqidah), Islamic Thoughts \& Religion and Society. https://orcid.org/0000-0001-5002-8827

Alia Sa'ad Eldin Abusahyon is a senior lecturer of the English Language Department, Preparatory Year College at Najran University in the last 6 years. In the meantime, she is also a postgraduate student in the Department of Languages, Literacies, and Translation in the School of Humanities at the Universiti Sains Malaysia. Previously she graduated from the Yarmuk University in Jordan. https://orcid.org/0000-0003-0254-248X

\section{References}

Abdul Malik Karim Amrullah (HAMKA). (2015). Tafsir al-Azhar. Gema Insani.

Abu Amsha, K. (1997). Arabic teaching in Andalusia and the ways of benefiting from it in teaching Arabic as a second language.

Airil Haimi Mohd Adnan. (2017). Being English Teachers in Malaysian Islamic Schools: Identity Narratives from a Five Year 'Life Journey'. Arab World English Journal, 8(1), 220-233. https://doi.org/https://dx.doi.org/10.24093/awej/vol8no1.16

Al-Faruqi, I. R. (1986). Toward Islamic English. International Institute of Islamic Thought.

Almaany. (2019). Translation and Meaning of Almaani in English - Arabic Terms Dictionary. https://www.almaany.com/en/dict/ar-en/al-maani/

Amat Juhari Moain, \& Wan Mohd Saophy Amizul Wan Mansor. (2016). Kata-kata Pinjaman Bahasa Arab dalam Bahasa Melayu: Perubahan Bunyi dan Makna [tr. The Arabic Loanwords in the Malay Language: The Changes of Sound and Meaning] (1st ed.). Dewan Bahasa dan Pustaka.

Ammar bin Fadzil. (2011). Deviant Teachings in Malaysia and Theirs Interpretation of the Qur' ān. International Journal of Humanities and Social Science, 1(20), 183-194.

Azirah Hashim, \& Leitner, G. (2016). Communicating with Asia - The Future of English as a Global Language. In G. Leitner (Ed.), Part I - English in selected regional and national habitats with a glance at the role of outward-bound communication needs (pp. 85-101). Cambridge University Press. https://doi.org/https://doi.org/10.1017/CBO9781107477186.007

Cresswell, J. W. (2007). Qualitative Inquiry and Research Design (2nd ed.). SAGE Publication of Thousand Oaks.

Dewan Bahasa dan Pustaka Malaysia. (2017). Pusat Rujukan Persuratan Melayu. http://prpm.dbp.gov.my/

Eaton, C. L. G. @ H. A. H. (1985). Islam and the Destiny of Man (1st ed.). State University of New York Press.

El-Helw, A., Mohiuddin, A., Dehkanov, S., Farra, A., Maher, H., Nafee, W., Fouad, A., Hossam, M., Mohammed, R., Essam, A., Al Ahmad, H., Abdelaal, A., Gabr, S., Said B, Saiyed, A., Tahri, N., Hussein, A., \& Jayyusi, M. (2017). Quran for Android App (3.0.4). quran.com.

Hafez, O. (1996). Phonological and Morphological Integration of Loanwords into Egyptian Arabic. Égypte/Monde Arabe, 27-28, 383-410. https://doi.org/10.4000/ema.1958

Haspelmath, M. (2009). Loanwords in the World's Languages: A Comparative Handbook (M. Haspelmath \& Uri Tadmor (Eds.); pp. 35-54). The Hague: de Gruyter Mouton. 
AWEJ for Translation \& Literary Studies Volume, 5 Number 4. October 2021

Haugen, E. (1950). The Analysis of Linguistic Borrowing. Language, 26(2), 210-231.

Higa, M. (1979). Sociolinguistic Aspects of Word Borrowing. In M. William \& J. Ornstein (Eds.), Sociolinguistic Studies in Language Contact: Methods and Cases (pp. 277-292). The Hague.

Hussein, A.-R. (2001). Qur'an Translation (1st ed.). Routledge. https://openmaktaba.com/wpcontent/uploads/books/Islamic-English-Books/\%28Culture and Civilization in the Middle East\%29 Hussein Abdul-Raof - Qur'an Translation_Discourse\%2C Texture and Exegesis-Routledge $\% 282001 \% 29 . p d f$

Hussein, A.-R. (2019). Text Linguistics of Qur'anic Discourse (1st ed.). Routledge . www.routledge.com/middleeaststudies/SE0363

Janesick, V. J. (2015). Peer Debriefing. Wiley Online Library. https://doi.org///doi.org/10.1002/9781405165518.wbeosp014.pub2

Jaspal, R., \& Coyle, A. (2010). "Arabic is the language of the Muslims-that's how it was supposed to be": exploring language and religious identity through reflective accounts from young British-born South Asians. Mental Health, Religion \& Culture, 13(1), 17-36. https://doi.org/10.1080/13674670903127205

Jones, R. (Comp. . (Ed.). (1978). III Arabic loan-words in Indonesian: a checklist of words of Arabic and Persian origin in Bahasa Indonesia and traditional Malay, in the reformed spelling.

Jones, R. (General E. ., Grijns, C. D., \& de Vries, J. W. . (Eds.). (2007). Loan-Words in Indonesian And Malay (1st ed.). Koninklijk Instituut voor Taal-, Land- en Volkenkunde (KITLV) Press, Institute of the Royal Netherlands Academy of Arts and Sciences (KNAW). https://web.archive.org/web/20120213003310/http://www.kitlv.nl/pdf_documents/asia-loan.pdf

Karũrũ, D. W. (2013). Borrowing and Communication in Language: The Impact of Morphological Adaptation Processes. International Journal of Education and Research, 1(9), 1-14. https://www.ijern.com/journal/September-2013/33.pdf

Khrisat, A. A., \& Majiduddin Sayyed Mohamad. (2015). Language's Borrowings: The Role of the Borrowed and Arabized Words in Enriching Arabic Language. American Journal of Humanities and Social Sciences, 2(2). https://doi.org/10.11634/232907811402533

Kubota, R., \& Miller, E. R. (2017). Re-Examining and Re-Envisioning Criticality in Language Studies: Theories and Praxis. Critical Inquiry in Language Studies, 14(2-3), 129-157. https://doi.org/10.1080/15427587.2017.1290500

Loveday, L. J. (1996). Language Contact in Japan: A Sociolinguistic History. Clarendon Press.

Manfredi, S., Simeone-Senelle, M.-C., \& Tosco, M. (2015). Language Contact, Borrowing and Codeswitching. In A. Mettouchi, M. Caubet, \& V. Dominique (Eds.), Corpus-based Studies of lesser-described Languages: the CorpAfroAs Corpus of spoken AfroAsiatic Languages (pp. 283308). John Benjamins. https://www.jbe-platform.com/content/books/9789027268891-09man

Masson, M.-E. (2013). How L1 Loanwords can Create a False Sense of Familiarity with L2 Vocabulary Meaning and Usage. Vocabulary Learning and Instruction, 2(1).

Matras, Y. (2009). Language Contact. Cambridge University Press. https://doi.org/https://doi.org/10.1017/CBO9780511809873

McMahon, A. (1994). Understanding Language Change. Cambridge University Press. https://doi.org/https://doi.org/10.1017/CBO9781139166591

Myers-Scotton, C. (1993). Duelling Languages: Grammatical Structure in Codeswitching. Clarendon. Noble Quran. (2020). Surah Al-Baqarah. NobleQuran. https://noblequran.com/surah-al-baqarah/

Noor Azlina Zaidan, Muhammad Azhar Zailaini, \& Ismail, W. M. (2015). Absorption of Arabic Words in Malay Language. OIDA International Journal of Sustainable Development 08:03, 8(3), 51-58. http://repository.um.edu.my/100336/1/SSRN-id2606870.pdf

Nurul-ikhlas Arshad, \& Mohamed Ismail Ahamad Shah. (2014). Lexical Borrowing from the Arabic Language in an Islamic Course Conducted in English. Middle-East Journal of Scientific Research (Language for Communication and Learning), 20, 110-117.

Arab World English Journal for Translation \& Literary Studies

ISSN: 2550-1542 | www.awej-tls.org 
AWEJ for Translation \& Literary Studies Volume, 5 Number 4. October 2021

https://doi.org/10.5829/idosi.mejsr.2014.20.1c1.217

Ottolini, L. (2014). Lexical Borrowing as a Sociolinguistic Phenomenon: Focus on Early Chinese Loanwords in English [Università degli Studi di Torino].

https://www.academia.edu/11694509/Lexical_Borrowing_as_a_Sociolinguistic_Phenomenon_Focu s_on_Early_Chinese_Loanwords_in_English

Ricquier, B. (2019). Historical Linguistics: Loanwords and Borrowing. In Oxford Research Encyclopedia of African History (pp. 1-18). Oxford University Press USA.

https://doi.org/10.1093/acrefore/9780190277734.013.362

Robins, R. H. (1964). General Linguistics: An Introductory Survey. Longmans.

Rozencvejg, V. J. (1976). Linguistic Interference and Convergent Change. Netherland.

Sapir, E. (1921). Language: An Introduction to the Study of Speech. Harcourt, Brace \& World.

Saussure, F. (2001). Course in General Linguistics (C. Bally \& A. Sechehaye (Eds.)). McGraw-Hill.

Stockwell, R., \& Minkova, D. (2002). English Words: History and Structure (2nd ed.). Cambridge University Press Cambridge. www.cambridge.org

Tarev, B. V. (2012). Lexical Borrowings: Linguistic and Didactic Aspects. Journal of Siberian Federal University - Humanities \& Social Sciences, 5, 944-950. https://doi.org/378.147:7.071.3(075.8)

Testen, D. (2019). Semitic languages. In Britannica. https://www.britannica.com/topic/Semitic-languages

Federal Constitution of Malaysia, 450 (2010) (testimony of The Malaysian Commissioner of Law). https://www.wipo.int/edocs/lexdocs/laws/en/my/my063en.pdf

The Mother Tongue Center - Arabic Language Learning. (2017). How Arabic Influences Other Languages Around the World. The Mother Tongue Center. https://mothertongue.ae/how-arabicinfluences-other-languages-around-the-world/

Thomason, S. G., \& Kaufman, T. (1988). Language Contact, Creolization, and Genetic Linguistics. University of California Press.

Traugot, E. C. (2019). Oxford Research Encyclopedia of Linguistics - Semantic Change. Oxford University Press. https://doi.org/10.1093/acrefore/9780199384655.013.323

Van Hout, R., \& Muysken, P. (1994). Modeling Lexical Borrowability. Language Variation and Change, 6(1), 39-62. https://doi.org/https://doi.org/10.1017/S0954394500001575

Versteegh, K. (2001). Linguistic contacts between Arabic and other languages. Arabica, 48(4), 470-508. https://doi.org/10.1163/157005801323163825

Wan Muhammad Marwan lsmail, \& Wan Moharani bin Mohammad. (2009). Kajian Semantik dan Mu'jam 'Arabiy [tr. Semantic Research and Arabic Dictionary]. Penerbit USIM.

Watson-Andaya, B., \& Andaya, L. Y. (1982). A History of Malaysia. Palgrave Publisher.

Weinreich, U. (1968). Languages in Contact: Findings and Problems (6th ed.). Mouton.

Whitney, W. D. (1881). On Mixture in Language. Transactions of the American Philological Association (1869-1896), 12, 5-26.

Wikipedia. (2021). Islam in Malaysia. Wikipedia. https://en.wikipedia.org/wiki/Islam_in_Malaysia

Winford, D. (2003). An Introduction to Contact Linguistics. Blackwell.

WordReference. (2021). homonymous. Dictionary of English - WordReference. https://www.wordreference.com/definition/homonymous

Zahavi, D. (2005). Subjectiviy and Selhood - Investigating the First-Person Perspective. The Massachusetts Institute of Technology (MIT) Press.

Arab World English Journal for Translation \& Literary Studies 